\title{
EDUTECH
}

Journal homepage : http://ejournal.upi.edu/index.php/edutech/index

\section{PROSEDUR PELAYANAN LEMBAGA KEPADA PUBLIK AKADEMIK DI SLB NEGERI A KOTA BANDUNG}

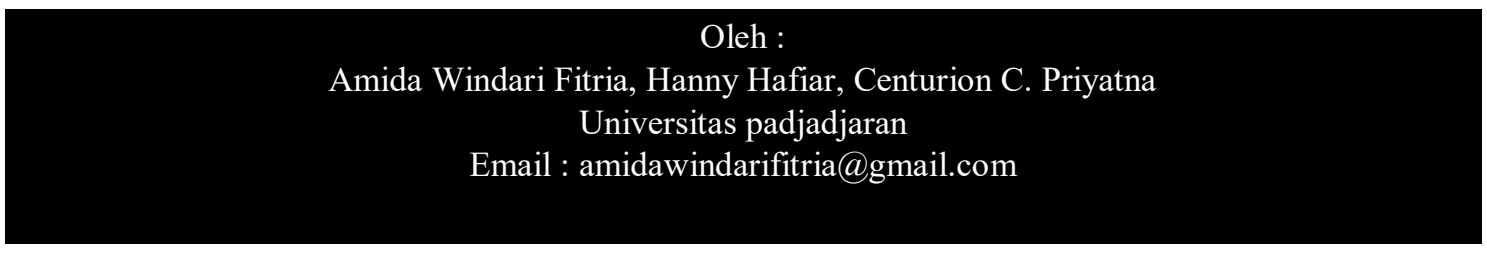

Abstract. Communication procedure in public service academic at SLBN A Bandung City, hasn't known by all public academic about the procedure. Some even made difficulties due to the stages that required the West Java Provincial Education Office first. Make a lot of academic public who repeat in making research letters conducted in SLBN A Bandung City. The uniqueness of this case study research lied in (1) the selection of research sites which are schools that provide special education for the visually impaired or previously known as the oldest extraordinary education in Southeast Asia. (2) Public Relations is not optimal in academic public services. (3) lies in a blind person who occupies the Deputy Principal for Public Relations and Advocacy in the SLBN A Bandung City. This study aims to know communication procedures in academic public services, the data in this research with qualitative approach is obtained through observation, in-depth interview, and literature study. The results showed that communication procedures in academic public services have seven procedures including Administration for PPL/PPG/KKN, Letter of Recommendation for the West Java Provincial Education Office for research, Disposition of Principals, Field Schedule Coordination, Conditioning Objects, Public Assistance by the Responsible Person / Teacher and Submitting the Activity Report.

\section{A. PENDAHULUAN}

Prosedur komunikasi dalam pelayanan publik akademik di Sekolah Luar Biasa (SLB) Negeri A Kota Bandung, tidak semua publik akademik mengetahuinya tahapantahapannya. Bahkan ada yang membuat kesulitan dikarenakan tahapan yang mengharuskan terlebih dahulu ke Dinas Pendidikan Provinsi Jawa Barat. Seperti yang disampaikan oleh Ibu Erna Rosiani selaku Wakil Kepala Sekolah Litbang SLB Negeri A Kota Bandung.

No. SK Akreditasi Ristekdikti : 34/E/KPT/2018
Informasi Artikel :

Artikel diterima 13 Juni 2019

Perbaikan 16 Maret 2019

Diterbitkan 28 Juni 2019

Terbit Online 30 Juni 2019

Kata kunci: Communication in Services, Academic Public, Procedure, SLB Negeri A Kota Bandung
"Untuk prosedurnya itu kita biasanya untuk penelitian skripsi, tesis jadi karya ilmiah gitu ya. Itu kita menerima surat terakhirnya itu yang dikeluarkan oleh Dinas Pendidikan Provinsi Jawa Barat. Kadangkala mahasiswa itu membawa surat dari kampus ditujukan kepada sekolah tapi kami tidak bisa menerima itu. Prosedur penelitian itu biasanya ditujukannya dari kampus ke kesbangpol. Dari kesbangpol tingkat provinsi yang di supratman. Sekarang DOI:https://doi.org/10.17509/e.v18i2.17143 
mekanismenya KCD 7 Dinas Pemprov"

Membuat banyak publik akademik yang mengulang kembali dalam pembuatan surat, peneliti harus membuat surat baru lagi dari kampusnya yang ditujukan ke Dinas Pendidikan Provinsi Jawa Barat. Sesuai arahan dan prosedur yang berlaku di SLB Negeri A Kota Bandung yang telah diutarakan oleh Koordinator Litbang di atas.

Penelitian ini menjadi penting dilakukan karena akan membantu dalam mewujudkan pelayanan yang lebih baik di lingkungan sekolah. Sehingga penelitian mengenai komunikasi dalam pelayanan kepada publik akademik ini akan menghasilkan suatu model komunikasi pelayanan yang dapat dilakukan di SLB Negeri A Kota Bandung. Sebab salah satu fungsi humas dalam manajemen sekolah adalah melakukan peranan komunikasi dan pengelola saluran informasi (management of communication) demi tercapai pemahaman suatu permasalahan (Rahmad, 2016).

Peran Humas dalam menyampaikan informasi-informasi penting dan hanya $\mathrm{Hu}-$ mas yang diberikan tugas untuk menyampaikan itu semua. Sehingga informasi 'satu pintu' membuat nyaman bagi para publik eksternal yang berniat melakukan kerjasama dengan lembaga yang dinaungi akan mendapatkan keuntungan ketika pelayanan yang diberikan diterima pertama oleh seorang Humas. Membuat informasi yang diterima oleh publik menjadi akurat tidak 'simpang siur' karena apabila Humas yang sudah menginformasikan, itu semua sudah merupakan keputusan dari pimpinan lembaga tersebut. Hal ini berdampak pada pengembangan strategi yang dapat dilakukan humas sekolah (Kurnia, Santoso, \& Rahmanto, 2013).

Memang seharusnya Humas berada dalam manajemen karena secara khusus Humas yang mendukung terciptanya saling pengertian dalam komunikasi, pemahaman, penerimaan, kerja sama antara organisasi dan berbagai publiknya. Sebab, salah satu pertimbangan publik untuk memilih sekolah sebagai tempat berkegiatan adalah adanya komunikasi yang jelas dan lancar (Prastantri, Novianti, \& Romli, 2017).

Keberadaan Humas sebagai suatu Lembaga akan mudah menciptakan saling pengertian dalam komunikasi. Humas yang memang berada dalam ranah ilmu komunikasi, akan memahami bagaimana sebuah informasi atau pesan yang akan disampaikan kepada publik sehingga dapat diterima dan dimengerti dan pada akhirnya mendapatkan pemahaman yang sama pada informasi tersebut, tidak terjadi misunderstanding. Karena salah satu persyaratan atau kualifikasi dasar untuk menjalani profesi Humas yakni ability to communicate (kemampuan berkomunikasi) hal ini tidak bisa ditawar-tawar lagi, baik halnya dalam komunikasi lisan maupun tulisan sesuai yang diungkapkan Frank Jefkins dalam (Ardianto, 2011:91)

Publik akademik seperti peneliti yang berasal dari universitas-universitas sesuai dengan data yang tercatat oleh SLB Negeri A Kota Bandung sampai pada bulan Agustus 
2018 adalah sebanyak 14 orang yang melakukan Program Pengalaman Lapangan (PPL) dimana memerlukan 3 bulan untuk mengikuti program tersebut. Diikuti tidak hanya dari universitas Pendidikan Indonesia di Bandung namun ada juga mahasiswa yang berasal dari luar Jawa Barat yakni Aceh. Selain PPL, terdapat 5 orang yang melakukan Program Pendidikan Profesi Guru (PPG) yang memerlukan waktu 1 tahun untuk menyelesaikan programnya. Sedangkan untuk jumlah peneliti yang melakukan penelitian di SLB Negeri A Kota Bandung ada 5 orang dari berbagai jenjang mulai penelitian skripsi sampai disertasi.

SLB Negeri A Kota Bandung memperkenalkan kebijakan dan prosedur dari Lembaga karena banyak sekali publik akademik yang melakukan observasi, penelitian Skripsi, Tesis dan Disertasi dan para mahasiswa yang melakukan Praktek Pekerjaan Lapangan. Maka 6 bulan kebelakang ini sudah diterapkan prosedur yang harus ditaati oleh para publik akademik dimana harus menandatangani sebuah perjanjian yang menyatakan bahwa kesanggupan untuk menaati aturan yang sudah dijelaskan didalamnya. Berdasarkan hal tersebut maka dapat dijabarkan fokus penelitian dalam penelitian ini sebagai berikut. "Prosedur dalam Pelayanan Lembaga kepada Publik Akademik di SLBN A Kota Bandung."

Dalam manajemen pendidikan di sekolah humas mempunyai kedudukan, yang mana kedudukan humas tersebut dalam organisasi sekolah telah dikemukakan oleh

No. SK Akreditasi Ristekdikti : 34/E/KPT/2018
Suryosubroto dalam (Rahmad, 2016: 78) sebagai berikut. Pertama, Jika dilihat dari sudut pandang manajemen, humas adalah suatu realisasi fungsi komunikasi sementara tugas humas itu sendiri merupakan salah satu fungsi manajemen. Kedua, Jika ditinjau dari sudut pandang administrasi pendidikan, humas adalah bagian atau salah satu komponen kegiatan administrasi pendidikan, dalam hal ini di sekolah. Realisasinya adalah kegiatan yang dilakukan sekolah bersama-sama dengan masyarakat. Kegiatan sekolah yang berhubungan dengan masyarakat diarahkan pada terciptanya kerja sama yang harmonis antara sekolah dan masyarakat.

Memang pada kenyataannya posisi humas dalam struktur organisasi sekolah di Indonesia baik sekolah negeri maupun sekolah swasta sangat beragam. Hal ini dikarenakan faktor eksistensi sekolah disesuaikan dengan situasi dan kondisi yang ada di masing-masing sekolah, seperti jumlah siswa, manajemen sekolah, peraturan yang berlaku, dan sebagainya.

Hubungan lembaga pendidikan dengan masyarakat pada hakikatnya merupakan suatu sarana yang sangat berperan dalam membina dan mengembangkan pertumbuhan pribadi peserta didik di sekolah. Dalam hal ini sekolah merupakan bagian yang integral dari sistem sosial yang lebih besar, yaitu masyarakat. Sekolah dan masyarakat memiliki hubungan yang sangat erat dalam mencapai tujuan sekolah, oleh karena itu hubungan sekolah dengan masyarakat harus dibina suatu hubungan yang harmonis 
(Rahmad, 2016: 78-79).

Penelitian ini menggunakan metode studi kasus yang bersifat eksploratif maka penelitian ini akan menyajikan apa yang sebenarnya terjadi di SLB Negeri A Kota Bandung dalam hal pelayanan yang diberikan kepada publik akademik yang bertujuan untuk melakukan penelitian ataupun kegiatan sejenisnya di sekolah tersebut. Teknik pengumpulan data dengan menggunakan teknik wawancara dan observasi. Penentuan key informan dipilih melalui teknik purposif dan diperoleh sejumlah narasumber yang terdiri dari pihak manajemen sekolah, meliputi kepala sekolah, humas, guru, siswa, dan alumni. Sedangkan dari pihak di luar manajemen sekolah diperoleh orangtua siswa, publik akademik yang tengah melakukan kegiatan, kerja lapangan, penelitian dan pengabdian.

\section{B. HASIL DAN PEMBAHASAN}

Peneliti telah melakukan wawancara mendalam dengan lima belas orang narasumber yang sudah dipaparkan diatas. Seluruh informan berperan untuk memberikan informasi mendalam mengenai komunikasi dalam pelayanan kepada publik akademik. Peneliti juga melakukan observasi partisipan untuk mengetahui lebih dalam mengenai prosedur pelayanan dan model komunikasi di SLB Negeri A Kota Bandung.

SLBN A Kota Bandung sebagai satusatunya sekolah negeri khusus untuk tunanetra yang berada dibawah Kementerian Sosial Republik Indonesia. Selain sekolah di dalam lokasi yang sama juga terdapat Panti
Sosial Wyata Guna (PSBN) yang dimana terdapat asrama-asrama untuk menjadi tempat tinggal bagi mereka dengan fasilitas yang sudah disiapkan dan mendukung dalam aktivitas sehari-hari penyandang tunanetra.

Prosedur komunikasi dalam pelayanan publik akademik. Berikut akan dijelaskan hasil penelitian yang ditemukan di lapangan setelah melalui tahapan wawancara dan observasi partisipan mengenai prosedur komunikasi dalam pelayanan di SLB Negeri A Kota Bandung terhadap publik akademik. Prosedur merupakan tahapan-tahapan yang harus dilalui oleh publik akademik yang akan melakukan program PPL (Program Pengalaman Lapangan), PPG (Program Profesi Guru), PKL (Praktek Kerja Lapangan), Penelitian berupa skripsi, tesis, disertasi dan penelitian lainnya yang bersifat ilmiah yang memerlukan objek penelitian yang berada di SLBN A Kota Bandung. Untuk mengetahui lebih dalam dan jelas berikut dipaparkan mengenai prosedurnya.

Menghubungi Tata Usaha (TU) bagi PPL/PPG/PKL/Pengabdian.

Untuk publik akademik yang akan melakukan program PPG (Pendidikan Profesi Guru) seperti yang dilakukan oleh Lutfi Pradnya yang berasal dari Universitas Pendidikan Indonesia menuturkan bagaimana prosedur untuk melakukan program PPG di SLB Negeri A Kota Bandung.

Biasanya khusus untuk buat sekolahsekolah yang sudah bermitra sama UPI. Dari prodi biasanya sama kami mahasiswa PPG nya diberikan ke sekolah. Kalau misalnya 
dari sekolah ke bagian litbang dan humas. Litbang nya bu Erna itu penelitian atau PPG dan sebagainya. Dari bu Erna ke TU bagian administrasi. Dari sana ditentukan kapan penerimaannya. Setelah dari TU dan disetujui oleh Bapak Sekolah nanti baru ditentukan kapan kami bisa mulai disini (Hasil wawancara dengan Lutfi Pradnya di SLB Negeri A Kota Bandung tanggal 6 November 2018/ 11:27 WIB).

Program PPG harus diselesaikan selama satu tahun di sekolah yang sudah bermitra dengan kampusnya masing-masing, dimana sekolah yang sudah bermitra ini adalah SLBN A Kota Bandung. Universitas Pendidikan Indonesia atau yang dikenal dengan sebutan kampus UPI. Kampus UPI memang memiliki Program Studi Pendidikan Khusus dimana Prodi ini untuk menyiapkan tenaga kependidikan yang mempunyai kemampuan dalam bidang Pendidikan luar biasa dimana mahasiswa yang melakukan PPG di SLBN A Kota Bandung memiliki spesialis dalam Pendidikan anak Tunanetra. Untuk melaksanakan PPG dari pihak kampus UPI khususnya Prodi Pendidikan Khusus yang pertama kali mengeluarkan surat pengantar PPG. Selanjutnya surat pengantar tersebut diserahkan kepada sekolah dan langsung ditujukan kepada Bagian Litbang dan Bagian Humas. Salah satu tugas Litbang di SLBN A Kota Bandung adalah menerima dan mengarahkan mahasiswa yang akan melakukan penelitian.

Namun bagi publik akademik yang melakukan PPL (Program Pengalaman
Lapangan) itu harus menyelesaikan programnya selama tiga bulan seperti yang dilakukan oleh Emi Ramadhana yang berasal dari Universitas Pendidikan Indonesia (UPI) prosedurnya adalah dari P2JK diambil langsung buat ke sekolah. Jadwalnya ditentukan, semua kelas dimasuki dan digilir. Jadi prosedurnya dari kampus ya. Lalu ketua PPL yang mengambil surat tugas tersebut dan didampingi oleh dosen dari kampus disaat di awal (Hasil wawancara dengan Emi Ramdhana di SLB Negeri A Kota Bandung tanggal 6 November 2018/ pukul 10:33 WIB).

P2JK (Pendidikan Profesi dan Jasa Keprofesian) merupakan Divisi yang memiliki tugas dan fungsi yaitu melaksanakan dan mengorganisasikan pelaksanaan kegiatan Pendidikan Profesi dan Jasa Keprofesian, salah satunya melaksanakan kegiatan Program Pengalaman Lapangan (PPL) Kependidikan. Berbeda dengan PPG, dimana PPL ini memiliki ketua dari setiap kelompok yang melakukan PPL di sekolah. Satu kelompok beranggotakan 15 orang. Ketua kelompok tersebut yang mengurus semua perizinan untuk masuk ke sekolah. Ketua kelompok mengambil surat pengantar dari P2JK dan memberikan ke sekolah. Seusai diterima oleh sekolah dimana yakni SLBN A Kota Bandung. Pihak sekolah menyusun jadwal bagi mahasiswa PPL yang beranggotakan 15 orang ini untuk masuk mengajar dan secara bergantian juga mengajar di semua kelas jadi tidak hanya diam di satu kelas tapi bergantian.

DOI:https://doi.org/10.17509/e.v18i2.17143 
Dikutip di halaman website (scribd.com, n.d.) mengenai pedoman PPL. Ternyata disebutkan bahwa PPL Kependidikan merupakan salah satu mata kuliah yang termasuk kelompok mata kuliah profesi pada program studi kependidikan yang bertujuan untuk mengembangkan profesi kependidikan. Melalui PPL kependidikan, para mahasiswa tidak hanya dituntut perkuliahan sesuai dengan tuntutan nyata dalam situasi kerja, tetapi para mahasiswa juga dituntut untuk mendapat pengalaman mengajar secara profesional serta mengintegrasikan pengalamannya ke dalam pola perilaku dirinya sebagai pribadi yang efektif dan produktif.

Selaku guru di SLBN A Kota Bandung dan juga menjabat sebagai Koordinator Perpustakaan, Ibu Yuniati memberikan jawaban mengenai prosedur untuk PPG/PPL bahwa: biasanya ya kalau yang PPG/PPL itu langsung ke TU lalu diarahkan ke Bu Erna bagian Litbang neng. Lalu bu Erna memberikan ke kita-kita (hasil wawancara dengan Ibu Yuniati di SLB Negeri A Kota Bandung tanggal 6 November 2018/ 13:33 WIB).

Bagian Tata Usaha di SLBN A Kota Bandung menjadi pintu pertama bagi publik akademik yang akan melaksanakan PPL atau PPG. Salah satu tugas fungsi dan pokok petugas Tata Usaha di SLBN A Kota Bandung (lihat tabel 2.7) adalah pengelolaan dan pengarsipan surat-surat masuk dan keluar. Bagi guru-guru di SLBN A Kota Bandung selesai mengurus masalah perizinan kegiatan baik PPL ataupun PPG oleh

No. SK Akreditasi Ristekdikti : 34/E/KPT/2018 publik akademiknya. Kemudian bagian Tata Usaha menghubungi Koordinator Litband dimana yakni Ibu Erna. Maka instruksi terakhir berada dari Koordinator Litbang yang menginformasikan kepada setiap guru mengenai kehadiran publik akademik yang akan melakukan programnya masingmasing.

Tabel 1. Tupoksi Petugas Tata Usaha SLBN A Kota Bandung

Sumber: Arsip SLBN A Kota Bandung

TUGAS POKOK DAN FUNGSI (TUPOKSI) PETUGAS TATA USAHA

Bertanggung jawab kepada Kepala Sekolah dalam kegiatan:

1.

2.

Penyusunan program kerja tata usaha sekolah

Pengelolaan dan pengarsipan suratsurat masuk dan

3. keluar

Pengurusan dan pelaksanaan admin-

4. Pembinaan dan pengembangan karir pegawai tata usaha sekolah

5. Penyusunan administrasi sekolah meliputi kurikulum, kesiswaan dan ketenagaan

6. Penyusunan dan penyajian data/statistik sekolah secara kese-

luruhan

7. Penyusunan tugas staf Tata Usaha dan tenaga teknis lainnya

8. Mengkoordinasikan dan melaksanakan 9

9. Penyusunan laporan pelaksanaan secara berkala

Litbang merupakan bagian yang menerima dan mengarahkan mahasiswa

DOI:https://doi.org/10.17509/e.v18i2.17143 
yang akan melakukan penelitian di SLBN A Kota Bandung. Adapun yang dipaparkan oleh Citra sebagai mahasiswa Unpad yang melakukan KKN di SLB Negeri A Kota Bandung perihal prosedur melakukan kegiatan pengabdian di sekolah menyatakan bahwa prosedurnya pertama ke ruang Tata Usaha, bertanya pada pihak sekolah yang mengatur jalannya suatu acara, biasanya diberikan kepada guru atau karyawan di sekolah (hasil wawancara dengan Citra di aplikasi chatting Whatsapp tanggal 28 November 2018 pukul 14:24 WIB).

Program KKN (Kuliah Kerja Nyata) Universitas Padjadjaran merupakan program rutin tahunan. Untuk prosedur melaksanakan KKN di SLBN A Kota Bandung sama halnya dengan PPL/PPG/ PKL menghubungi Bagian Tata usaha untuk menanyakan mengenai informasi pengabdian di sekolah. Selanjutnya pihak sekolah yang menentukan waktu untuk lebih lanjut menghubungi guru atau karyawan yang dapat membantu menyelesaikan program KKN serta mendampingi mahasiswa KKN di lingkungan SLBN A Kota Bandung.

Sedikit informasi mengenai program KKN dari Universitas Padjadjaran. Program ini berbeda dengan $\mathrm{KKN}$ biasanya dimana apabila program KKN ini lebih banyak terjun ke desa-desa yang jauh dari jangkauan. Namun terdapat perbedaan pada tahun 2018 dimana program KKN ini terintegrasi dengan implementasi hibah program Pengabdian pada Masyarakat (PPM) yang dilakukan oleh para dosen. Maksudnya dosen yang menjadi Dosen Pendamping Lapangan (DPL) yang ditetapkan dalam KKN ini merupakan dosen yang judul riset PPM-nya terpillih untuk diintegrasikan dengan program KKN. Sehingga Citra selaku ketua tim dalam KKN ini memberitahu bahwa Dosen Pendamping Lapangan (DPL) adalah Ibu Hanny Hafiar dimana sebelumnya beliau telah melaksanakan PPM di SLBN A Kota Bandung.

Program KKN memiliki masa waktu 14 minggu dengan beban studi 3 SKS. Maka setiap minggunya, KKN dilaksanakan sekitar 8-9 jam. Namun menyerahkan kembali mekanisme pelaksanaan KKN kepada setiap-setiap dosen. Setiap kelompok KKN diisi oleh 10 sampai 11 mahasiswa dari lima program studi di Universitas Padjadjaran.

Semua prosedur tertuju pada bagian Tata usaha sebagai prosedur pertama melakukan penelitian di SLBN A Kota Bandung. Demikian prosedur pertama yang didapatkan dari hasil temuan peneliti di lapangan khusus untuk publik akademik yang melakukan program PPG/PPL/PKL/ KKN. Selanjutnya akan 
dipaparkan hasil temuan untuk prosedur kedua.

Surat Rekomendasi Dinas Pendidikan Provinsi Jawa Barat bagi penelitian.

Mematuhi prosedur yang ditetapkan oleh SLBN A Kota Bandung sudah menjadi suatu kewajiban untuk menaatinya. Seperti yang diungkapkan oleh seorang mahasiswa yang sedang melakukan penelitian untuk Skripsi yang bernama Hudayani Sabila Fitri mengenai prosedur yang ditempuh untuk melaksanakan penelitian di SLB Negeri A Kota Bandung menyebutkan bahwa cara saya bisa masuk ke sekolah untuk melakukan penelitian adalah menemui terlebih dahulu petugas TU yang khusus bertugas untuk menerima mahasiswa yang akan melakukan observasi/penelitian dan dengan membawa administrasi persuratan yang dibutuhkan (hasil wawancara dengan Hudayani Sabila Fitri di SLB Negeri A Kota Bandung tanggal 27 November 2018/ 13.27WIB).

Petugas Tata Usaha yang khusus menerima mahasiswa yang akan melakukan penelitian, dengan memberikan syarat-syarat keadministrasian untuk melengkapi dan bisa melakukan penelitian di SLBN A Kota Bandung. Namun pada kasus Hudayani tidak diceritakan bahwa harus meminta surat rekomendasi dari Dinas Pendidikan Provinsi

No. SK Akreditasi Ristekdikti : 34/E/KPT/2018
Jawa Barat. Karena seperti yang diutarakan oleh Koordinator Litbang yakni Ibu Erna Rosiani mengenai prosedur bagi publik akademik yang akan melakukan penelitian skripsi. Berikut hasil wawancaranya.

Untuk prosedurnya itu kita biasanya untuk penelitian skripsi, tesis jadi karya ilmiah gitu ya. Itu kita menerima surat terakhirnya itu yang dikeluarkan oleh Dinas Pendidikan Provinsi Jawa Barat. Kadangkala mahasiswa itu membawa surat dari kampus ditujukan kepada sekolah tapi kami tidak bisa menerima itu. Dari dulu bahwa prosedur penelitian itu biasanya ditujukannya dari kampus ke kesbangpol. Dari kesbangpol tingkat provinsi yang di supratman. Sekarang mekanismenya KCD 7 Dinas Pemprov (Hasil wawancara dengan Ibu Erna Rosiani di SLB Negeri A Kota Bandung tanggal 6 November 2018/ 15.33 WIB).

Tidak semua publik akademik mengetahui informasi ini, bahkan mungkin semua mahasiswa diluaran sana juga demikian. Karena biasanya ketika akan melakukan penelitian di tempat tertentu maka surat penelitian ditujukan langsung ke tempat tersebut. Beda halnya ketika mahasiswa yang akan melakukan penelitian di SLBN A Kota Bandung, sebelumnya surat yang dibuat dari kampus masing-masing itu ditujukan ke Kes- 
bangpol sesuai dengan yang diutarakan Ibu Erna diatas. Namun untuk sekarang bisa langsung ke Dinas Pendidikan Provinsi Jawa Barat yang beralamt di Jalan Dr. Rajiman No.6 Pasir Kaliki Cicendo Kota Bandung. Selesai melaui prosedur dari Dinas Pendidikan Provinsi Jawa Barat dan sudah mendapatkan surat rekomendasi dari Dinas Pendidikan Provinsi Jawa Barat dimana SLBN A Kota Bandung masuk ke dalam wilayah KCD (Kepala Cabang Dinas) 7 yakni Kota Bandung dan Kota Cimahi. Maka baru mahasiswa yang akan melakukan penelitian skripsi bisa masuk ke sekolah.

Hal yang samapun disampaikan oleh Ibu Muftiah selaku Triangulator untuk menemukan jawaban yang tepat. Berikut hasil penjelasan mengenai prosedur penelitian yang mengharuskan ke Dinas Pendidikan Provinsi Jawa Barat terlebih dahulu.

Kalau dibilang prosedur engga sulit sih. Kepala sekolah, kepala TU. Surat itu masuk ke TU lalu disahkan. Tapi ada aturan yang mengikat kami, karena kami dibawah dinas provinsi jabar. Kalau sifatnya penelitian kita harus lapor yang disebut dgn KCD (Kepala Cabang Dinas) atas rekomendasi dari pak KCD lah sehingga sekolah bisa menerima. Kalau sekolah pd prinsipnya sebagai fungsional, pendidik atau Lembaga kependidikan sangat senang ada dari unsur baik kampus atau dari apapun yang memang nanti punya apa ya. Punya minat ke sekolah melakukan baik itu penelitian pendampingan dan sebagainya. Hanya itu saja kalau untuk penelitian harus minta izin (Hasil wawancara dengan Ibu Muftiah Yulismi di Gedung Sate Bangunan A tanggal 12 November 2018/ 11:07 WIB).

Penelitian skripsi harus memiliki izin yakni berupa surat rekomendasi yang dikeluarkan oleh Dinas Provinsi Jawa Barat. Dengan surat rekomendasi tersebut maka penelitian dari mahasiswa yang bersangkutan akan diterima oleh SLBN A Kota Bandung. Diharapkan dari prosedur surat rekomendasi yang dikeluarkan oleh Dinas Pendidikan Provinsi Jawa Barat ini mengetahui bahwa banyak sekali mahasiswa yang melakukan penelitian di sekolah. Selain itu dengan banyaknya penelitian tersebut maka sekolah juga akan berkembang dengan temua-temuan yang didapatkan dari hasil penelitian tersebut. Sehingga SLBN A Kota Bandung akan menjadi lebih baik.

Alasan dari Bapak Yacobus Tri Bagio selaku Wakil Kepala Sekolah Bagian Humas dan Advokasi SLB Negeri A Kota Bandung mengapa untuk para peneliti harus melewati Dinas Pendidi- 
kan Provinsi Jawa Barat. Berikut pemaparannya.

Dari dinas mengeluarkan surat rekomendasi ke SLB. Nah langkahlangkahnya seperti itu. Mengapa itu dilakukan karena ini terkaitnya dengan penelitian terkaitnya dengan kebijakan pemerintah ya. Dalam hal ini supaya risetnya itu terpantau, fungsinya, outputnya, termasuk kebermanfaatnya. Ketika prosedur itu sudah ditempuh. Baru lakukan prosedur yang tadi pencatatan surat lalu kami langsung fokuskan kepada siapa nanti yang menangani (Hasil wawancara dengan Bapak Yacobus Tri Bagio di SLB Negeri A Kota Bandung tanggal 12 November 2018 pukul 13:39 WIB)

Sesuai dengan visi dari Dinas Pendidikan Provinsi Jawa Barat yakni terwujudnya Pendidikan maju di jawa Barat guna membentuk SDM yang berkarakter, cerdas, mandiri, menguasai IPTEK dan berbasis budaya Jawa Barat. Maka dituntut dari penelitian yang dilakukan di sebuah Lembaga naungan dari Dinas Pendidikan Provinsi Jawa Barat untuk memberikan manfaat guna ikut serta mewujudkan visi diatas. Selain itu melalui Dinas Pendidikan Provinsi Jawa Barat, izin penelitian yang akan kita lakukan di SLBN A Kota Bandung akan secara resmi dan akan mengurangi ham- batan di lapangan ketika melakukan penelitian. Karena sebelumnya sudah mendapatkan secara resmi izin dari Dinas Pendidikan Provinsi Jawa Barat.

Disposisi Kepala Sekolah

Berdasarkan hasil wawancara dengan Bapak Wawan selaku Kepala Sekolah SLB Negeri A Kota Bandung memaparkan mengenai prosedur ketiga bagi publik akademik adalah disposisi/ rekomendasi. Berikut hasil wawancara dengan Bapak Kepala Sekolah.

Secara prinsip surat permohonan dari Lembaga yang bersangkutan ditujukan kepada sekolah nanti akan diterima oleh bu eva untuk dicatatkan sebagai surat masuk dan itu harus satu pintu. Harus lari ke meja saya. Untuk dipelajari dan akan dibuatkan rekomendasi atau rujukan. Untuk penelitian A lebih tepatnya ke siapa yang B ke siapa. Berdasarkan kompetensi dan kemampuan individu (Hasil wawancara dengan Bapak Wawan di SLB Negeri A Kota Bandung tanggal 12 November 2018 pukul 13:36).

Selaku pimpinan di sebuah Lembaga, Kepala Sekolah memegang peranan penting dalam pelayanan kepada publik akademik. Berbagai perizinan dari luar harus diketahui oleh Kepala Sekolah untuk dilihat dan dikaji keperluannya apa. Disposisi ini yang mengetahui tentunya Kepala Sekolah, karena dis- 
esuaikan dengan keahlian yang dimiliki oleh karyawannya di SLBN A Kota Bandung. Disposisi tidak bisa dikeluarkan seenaknya karena menyangkut ke hasil penelitian nantinya.

Begitu pula dengan hasil wawancara dari mahasiswi Universitas Pendidikan Indonesia yang melakukan penelitian skripsi di SLB Negeri A Kota Bandung yang bernama Hudayani Sabila Fitri memaparkan bahwa setelah mendapat persetujuan bahwa mahasiswa dapat melakukan penelitian berupa tandatangan dari kepala sekolah maka mahasiswa diminta untuk menemui wakasek kurikulum yaitu ibu Rika untuk menyerahkan surat pernyataan penelitian tersebut (Hasil wawancara dengan Hudayani Sabila Fitri di SLB Negeri A Kota Bandung tanggal 27 November 2018 pukul 13:27 WIB).

Prosedur tahap ini merupakan pintu terakhir dalam perihal administrasi dan menjadi tiket masuk ke sekolah untuk publik akademik. Disposisi merupakan persetujuan tertulis dan resmi yang ditanda tangani oleh Kepala Sekolah untuk bisa masuk ke sekolah melakukan tujuan kegiatan masing-masing dari publik akademik.

\section{Koordinasi Jadwal Lapangan}

Berkomunikasi untuk mengatur jadwal kegiatan yang akan dilaksanakan di sekolah melalui KSP (Kepala Satuan Pendidikan) atau guru pamong, seperti yang dipaparkan dalam hasil wawancara dengan Bapak Yacobus Tri Bagio sebagai berikut, diarahkan kepada siapa sesuai dengan bidangnya. Katakanlah kalau meneliti observasi tentang SD berarti di lingkungan SD atau guru yang tepat atau wali kelas KSP atau jika keterkaitan dengan ruang lingkup layanan bimbingan berarti nanti kepada Koordinator Bimbingan Konseling seperti itu (Hasil wawancara dengan Bapak Yacobus Tri Bagio di SLB Negeri A Kota Bandung tanggal 12 November 2018 pukul 13:39 WIB).

SLBN A Kota Bandung memiliki KSP disetiap tingkat, berbeda dengan wali kelas. KSP disini merupakan ketua dari setiap jenjang Pendidikan. Ketika penelitian membutuhkan objek penelitiannya siswa SD maka KSP SD yang akan mendampingi dan memberikan informasi yang dibutuhkan oleh setiap peneliti.

Sama halnya dari Salma Kharisma Permatasari yang melakukan penelitian untuk skripsinya yang berasal Telkom University, memaparkan sebagai berikut, "ketemu itu sama guru BK waktu itu namanya bu mufti, lalu selanjutnya aku dikenalkan oleh ketua yangg megang tanggung jawab di smp gitu yaitu ibu 
Yuyun," (Hasil wawancara dengan Salma Kharisma Permatasari di SLB Negeri A Kota Bandung tanggal 30 November 2018 pukul 14:07 WIB).

Keberadaan orang yang mudah dihubungi yakni Ibu Mufti, membuat beberapa peneliti mendapatkan kemudahan. Melalui Ibu Mufti beberapa prosedur yang sedikit menggangu jalannya penelitian cepat teratasi. Namun Ibu Mufti juga tetap memberikan berkoordinasi dengan KSP untuk memenuhi kepentingan penelitian dari publik akademik tersebut.

Menyusun jadwal dengan KSP untuk menyesuaikan dengan waktu siswa dimana siswa di SLBN A Kota Bandung ini yang menjadi objek dalam penelitian. Keberadaan siswa di sekolah bagaimanapun tidak boleh mengganggu proses belajar mengajar. Sehingga disusunlah jadwal kegiatannya bersama KSP.

\section{Mengkondisikan Objek}

Objek disini di antaranya adalah siswa, orang tua siswa, alumni, guru dan staf di SLB Negeri A Kota Bandung. Mempersiapkan objek untuk diteliti ataupun mengisi kegiatan yang akan dilakukan oleh para publik akademik. Memberitahukan keberadaan publik akademik akan melakukan peneliti. Seperti yang dipaparkan oleh salah satu alumni SLB Negeri A Kota Bandung yakni Graciella Yolanda Siregar memaparkan bahwa, "iya kak selalu dikasih tahu kalau ada yang akan datang dari kampus mana buat nanya-nanya kayak wawancara gitu," (Hasil wawancara dengan Graciella Yolanda Siregar di SLB Negeri A Kota Bandung tanggal 6 November pukul 10:33 WIB).

Sekolah memberikan informasi mengenai publik akademik dari luar yang akan menemui siswanya. Dikarenakan siswa di sekolah ini tunanetra sehingga peran sekolah sangat penting dalam memberi tahu informasi kepada publik akademik mengenai kondisi siswanya di sekolah. Namun publik akademik harus menunggu dari pihak sekolah karena mereka yang sudah memang kendal dan dekat dengan siswanya. Sehingga tidak akan membuat kaget siswa, dengan pengantar dari sekolah yang menginformasikan kehadiran publik akademik. Membuat siswanya juga percaya dan mempersiapkan diri untuk menghadapi publik akademik tersebut.

Begitupula dengan Ibu Dewi sebagai orang tua dari siswa kelas tiga di SLB Negeri A Kota Bandung memaparkan bahwa, "paling gurunya yang bilang, terus kitanya mau apa tidaknya. Biasanya kalau saya mah harus liat dari gurunya," (Hasil wawancara dengan Ibu Dewi di SLB Negeri A Kota Bandung 
tanggal 12 November 2018 pukul 11:07 WIB).

Kepercayaan orang tua siswa kepada guru di SLBN A Kota Bandung sangat tinggi. Ketika guru yang menginformasikan sesuatu, orang tua siswa akan mudah menerimanya dan percaya. Tingkat kepercayaan ini yang dijadikan ukuran oleh Ibu Dewi sehingga bisa menerima publik akademik untuk melakukan penelitian atau wawancara.

Namun berbeda dengan Yusliati Anggraeni yang merupakan siswa SMA di SLB Negeri A Kota Bandung menyatakan bahwa, "enggak dikasih tau sekolah, mereka datang langsung nanyananya gitu. Lupa dari universitas mana. Enggak dibilang untuk penelitian apa. Wawancara selesai udah makasih ya udah gitu," (Hasil wawancara dengan Yusliati Anggraeni di SLB Negeri A Kota Bandung tanggal 6 November 2018 pukul 14:33 WIB).

Ada beberapa publik akademik yang membutuhkan data lapangan yang cepat. Sehingga mereka langsung datang menghampiri objek penelitiannya yakni siswa dan dari sekolah tidak memberitahu kembali bahwa peneliti tersebut datang kembali namun untuk mewawacarai siswa yang berbeda. Sehingga terjadi koordinasi yang sedikit bermasalah. Dimana publik akademik tersebut sudah merasa mendapatkan izin di hari sebelumnya tanpa meminta pihak sekolah mendampinginya kembali ke lapangan.

Sama halnya dengan Natalia Nindi Wijaya yang merupakan siswa SMP di SLB Negeri A Kota Bandung menyatakan bahwa, "engga ada kak, sekolah engga ngasih tau jadi mereka datang aja langsung ke kelas," (Hasil wawancara dengan Natalia Nindi Wijaya di SLB Negeri A Kota Bandung tanggal 6 November 2018 pukul 10:33 WIB).

Kondisi yang dialami seperti diatas sangat mungkin, karena dengan kondisi tunanetra siswa di SLBN A Kota Bandung tidak dapat membedakan mana publik akademik yang datang. Maka dari itu harus ada aturan yang lebih tegas dari pihak sekolah untuk publik akademik. Sehingga akan memberikan rasa nyaman dan aman bagi siswanya. Adapun penjelasan dari Ibu Muftiah sebagai triangulator menyatakan bahwa dalam pengkondisian objek di sekolah sebagai berikut.

Mempersiapkan siswa-siswa yang dibutuhkan oleh peneliti sebelumnya sudah didiskusikan kelas mana yang dibutuhkan dan kapan akan melakukan wawancara sehingga sebetulnya kami memang sudah mempersiapkannya jauhjauh hari. Namun apabila ada yang bilang bahwa sekolah tidak memberi tahu sebelumnya ke siswa. Itu mungkin 
karena mahasiwa yang bersangkutan membutuhkan data dengan cepat dan kebetulan kami tidak ada ditempat sehingga mereka langsung menemui siswa di kelas apabila tidak sedang melakukan kegiatan belajar (Hasil wawancara dengan Ibu Muftiah Yulismi di Gedung Sate Bangunan A tanggal 12 November 2018/ 11:07 WIB)

Koordinasi yang dilakukan sedikit terhambat sehingga membuat siswa yang sebagai objek penelitian merasa kaget karena tidak ada pemberitahuan sebelumnya. Menjadi sebuah pekerjaan rumah bagi SLBN A Kota Bandung karena sekolah ini berbeda dengan sekolah biasa. Sehinga memang diharuskan adanya koordinasi yang jelas mengenai aturan bertemu dengan siswa. Sehingga rasa tidak nyaman yang dialami oleh siswa akan terhindar. Karena siswa tunanetra yang hanya mengandalkan dari suara, mereka tidak akan mudah mendekati orang baru.

Begitu pula publik akademik harus dapat memahami kondisi siswa disana dan mempersiapkan banyak pengetahuan mendasar mengenai tunanetra. Sehingga hal-hal yang tidak diinginkan tidak terjadi di lapangan. Selain itu tingkat kesabaran dari publik akdemik dalam menghadapi siswa tunanetra harus lebih karena tidak mudah siswa tersebut dapat

No. SK Akreditasi Ristekdikti : 34/E/KPT/2018 langsung dengan mudah menjawab pertanyaan.

Pendampingan Publik Akademik oleh KSP/ Guru Pamong

Prosedur pendampingan ini dilakukan oleh sekolah untuk memberikan bantuan kepada publik akademik saat di kelas. Seperti yang dipaparkan oleh Bapak Yacobus Tri Bagio seperti dibawah ini.

Biasanya nanti kami siapkan guru pamong yang mendampingi sampai nanti misalnya ada treatment ada intervensi atau kalau ada action research melakukan perlakuan baru merumuskan nanti hasil yang BAB 4 itu biasanya kami meminta dibagian akhir karena kami juga mengeluarkan rekomendasi bahwa mahasiswa tersebut benar-benar melakukan penelitian seperti itu (Hasil wawancara dengan Bapak Yacobus Tri Bagio di SLB Negeri A Kota Bandung tanggal 12 November 2018 pukul 13:39 WIB)

Untuk PPG (Program Profesi Guru) dan PPL (Program Pengalaman Lapangan) yang selalu didampingi setiap hari dalam melaksanakan programnya. Dimana setiap hari publik akademik mengajar, namun dalam setiap minggu juga harus membuat laporan dan juga untuk satu minggu kedepan membuat rancangan pembelajaran untuk di kelas. Keberadaan guru pamong di SLBN A 
Kota Bandung untuk memberikan penilaian di akhir programnya. Maka publik akademik yang melaksanakan PPG selama satu tahun di sekolah akan terus didampingi oleh guru pamong tersebut.

Hal yang samapun dituturkan oleh Emi Ramadhana sebagai publik akademik yang melakukan PPL di SLBN A Kota Bandung. Berikut hasil wawancaranya, "iya kami memiliki guru pamong dimana setiap minggu harus mengerjakan rancangan pembelajaran dan nanti kita juga dinilai oleh guru pamong tersebut," (Hasil wawancara dengan Emi Ramdhana di SLB Negeri A Kota Bandung tanggal 6 November 2018/ pukul 10:33 WIB).

Penilaian yang dilakukan oleh guru pamong diliat seberapa jauh menguasai mata pelajaran dan cara menyampaikannya ketika di kelas, serta seberapa rajin masuk di kelas. Mata pelajaran yang dipersiapkan harus sesuai dengan kurikulum serta diberikan tugas-tugas yang sesuai dengan kondisi siswa sehingga membuat suasana kelas tidak bosan. Karena siswa tunanetra di SLBN A Kota Bandung melewati hari-hari di kelasnya dengan mengandalkan pendengaran. Sehingga mahasiswa PPG di kelas harus dapat membuat sesuatu yang berbeda dari guru biasanya. Namun sebelumnya telah dikonsultasikan terlebih dahulu dengan guru pamong.

Beda halnya dengan Hudayani yang melakukan penelitian skripsi menyatakan bahwa, "saat saya meneliti anak di kelas, saya membaur dengan kegiatan pembelajaran Bersama gurunya. Tidak ada orang khusus dari pihak sekolah yang mendampingi saat saya penelitian di kelas," (Hasil wawancara dengan Salma Kharisma Permatasari di SLB Negeri A Kota Bandung tanggal 30 November 2018 pukul 14:07 WIB).

Tidak seperti publik akademik yang melakukan PPG dan PPL, untuk yang penelitian skripsi tidak terlalu sering didampingi bahkan ada yang tidak perlu ditemani karena sudah merasa diantarkan dan diberi izin oleh guru di kelasnya. Jadi publik akademik beradaptasi dengan sendirinya dan mencoba memahami keadaan sekolah sekitar dengan melihat langsung.

Demikian prosedur yang harus ditaati ketika berada di lapangan yakni lingkungan sekolah. Selanjutnya akan dipaparkan mengenai prosedur terakhir yang harus dilakukan publik akademik di SLBN A Kota Bandung.

Menyerahkan Laporan Hasil Kegiatan

Prosedur terakhir yang harus dilalui dan juga merupakan sebagai bentuk per-

DOI:https://doi.org/10.17509/e.v18i2.17143 
tanggung jawaban dari publik akademik adalah menyerahkan laporan dari hasil penelitian yang telah dilakukan di SLBN A Kota Bandung. Berikut yang dipaparkan oleh Hudayani, "betul sekali, selesai dari penelitian ini. Saya ditunggu untuk menyerahkan satu hardcopy skripsi ke sekolah sebagai laporan dan nantinya uang jaminan yang disimpan sebanyak 300ribu akan dikembalikan," (Hasil wawancara dengan Salma Kharisma Permatasari di SLB Negeri A Kota Bandung tanggal 30 November 2018 pukul 14:07 WIB).

Kebijakan baru mengenai komitmen publik akademik dengan SLBN A Kota Bandung dilakukan karena beberapa alasan dari pihak sekolah yang sudah diutarakan langsung kepada publik akademik. Dimana yang menyampaikannya itu adalah Bapak Kepala Sekolah. Dengan komitmen tersebut publik akademik dituntut untuk bisa saling menjaga dan yang pada akhirnya kedua pihak akan merasa saling diuntungkan. Karena publik akademik merasa terbantu dengan penelitian yang bisa dilaksanakan di sekolah, serta sekolah juga lebih merasa terbantu dengan kehadiran peneliti dari luar yakni bisa mengembangakan dan memberikan temuan yang baru untuk siswa ataupun sekolah.

No. SK Akreditasi Ristekdikti : 34/E/KPT/2018
Begitu pula dengan yang dituturkan oleh Bapak Yacobus selaku Wakasek Humas SLBN A Kota Bandung mengenai penyerahan laporan, "penyerahan laporan berupa hasil penelitian sebenarnya merupakan kontribusi besar untuk Lembaga kami bukan hanya untuk penelitian pengembangan. Tapi bagaimana pengembangan itu berangkat dari hasil laporan resmi, skripsi tesis itu dokumen negara," (Hasil wawancara dengan Bapak Yacobus Tri Bagio di SLB Negeri A Kota Bandung tanggal 12 November 2018 pukul 13:39 WIB).

Dokumen negara yang dikembangkan baik berupa skripsi, tesis maupun disertasi. Secara resmi dan hokum diakui oleh negara, maka dari itu hasil penelitian sekecil apapun akan sangat berpengaruh dan berdampak pada Lembaga yakni SLBN A Kota Bandung. Kehadiran publik akademik membawa pengaruh besar dan menjadikan SLBN A Kota Bandung sebagai resource center. Maka sekolah tidak akan pernah berhenti dan menyambut kedatangan publik akademik untuk melakukan penelitian.

Prosedur untuk melakukan penelitian atau kegiatan lain dari publik akademik sudah dipaparkan diatas. Ada tujuh (7) prosedur yang harus dilakukan sehingga dapat masuk dan menyelesaikan 
penelitian dengan baik di SLBN A Kota

Bandung. Berikut dibawah ini merupa-

kan model prosedur pelayanan di SLBN

A Kota Bandung. Sehingga dapat dilihat dan dipahami lebih mudah melalui gambar berikut:

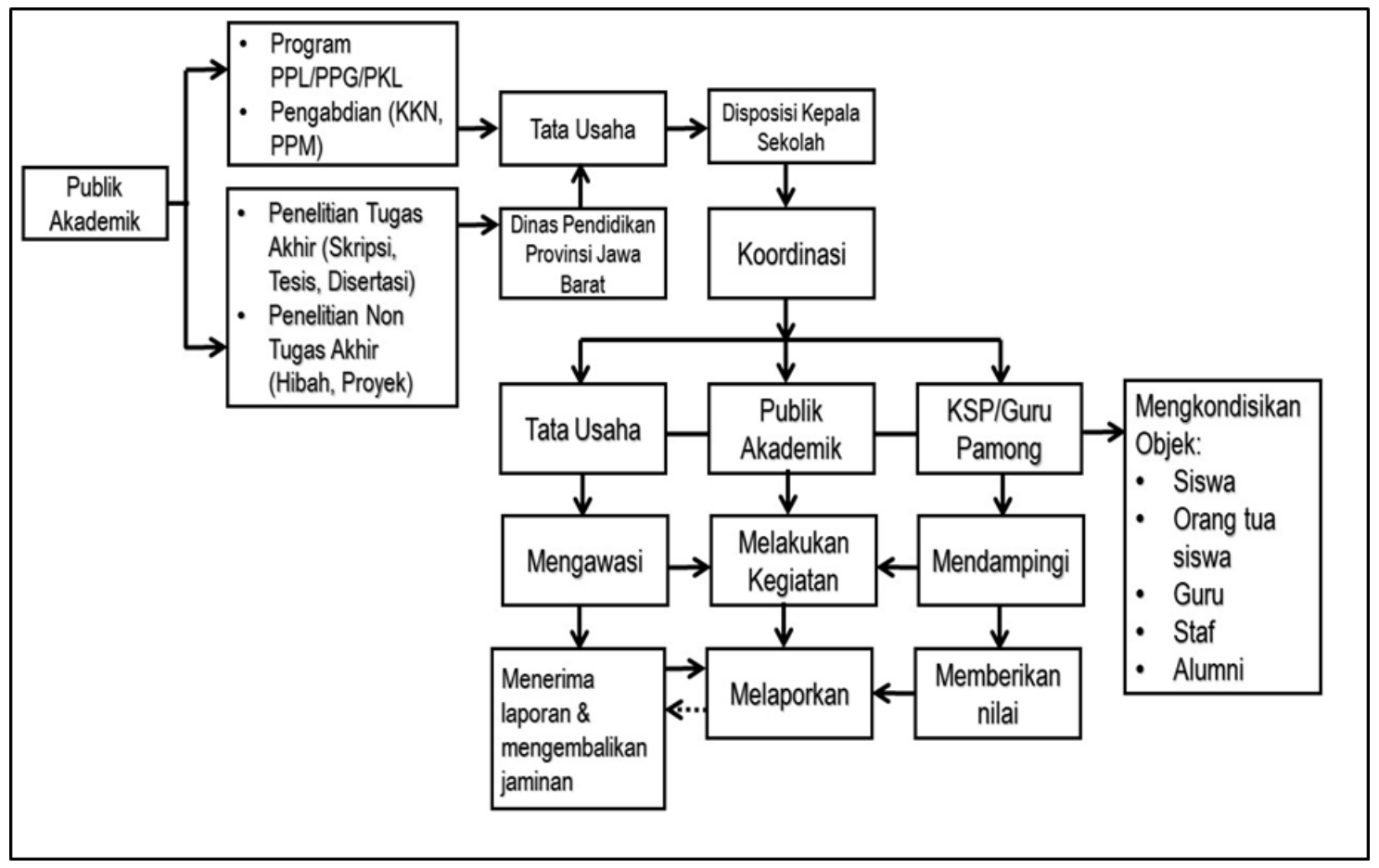

Gambar 1. Prosedur Komunikasi dalam Pelayanan Publik Akademik Sumber: Data Penelitian Lapangan 2018

Prinsip sebuah pelayanan adalah koordinasi dan komunikasi. Dimana semua bagian dari Lembaga atau instansi harus dapat saling berkoordinasi dan berkomunikasi dengan baik sehingga pelayanan yang diberikan akan jelas dan tidak membuat bingung publik.

Setiap publik memiliki pengaruh pada Lembaga, terutama publik akademik dimana yang merupakan seseorang berpendidikan tinggi, atau intelektual, atau seseorang yang menekuni profesi sebagai pengajar dan guru besar di perguruan tinggi. Sehingga pengaruh dari publik akademik ini akan membantu dalam pengembangan sekolah khususnya SLBN A Kota Bandung menjadi yang lebih baik dari segi pembelajaran maupun fasilitas khusus untuk siswa tunanetra yang akan membantu dalam kehidupan sehari-harinya.

Menurut Somantri dalam (Pratama et al., 2016 : 14), Tunanetra merupakan sebuah kondisi manakala seseorang mengalami keterbatasan penglihatan. Keterbatasan penglihatan ini akan berakibat pada terbatasnya mereka untuk melihat. Begitupu- 
la menurut (Isharwati, 2008) penyandang tunanetra dikategorikan pada kondisi yang mengacu pada hilangnya fungsi indra visual sesorang.

Untuk dapat masuk ke SLBN A Kota Bandung tidaklah mudah karena ada beberapa prosedur yang harus ditempuh sehingga bisa melakukan penelitian di sekolah tersebut. Salah satunya bagi penelitian skripsi, tesis, disertasi dan observasi lainnya diharuskan melalui Dinas Pendidikan Provinsi Jawa Barat terlebih dahulu sebagai pintu masuknya.

Menurut (kbbi.web.id, n.d.) prosedur memiliki dua pengertian yakni tahap kegiatan untuk menyelesaikan suatu aktivitas dan metode langkah demi langkah secara pasti dalam memecahkan suatu masalah. Sehingga prosedur pelayanan di SLBN A Kota Bandung merupakan kegiatan untuk menyelesaikan suatu aktivitas yakni berupa pelayanan yang diberikan kepada publik akademik oleh sekolah.

Definisi pelayanan yang sangat simpel diberikan oleh Ivancevich, Lorenzi, Skinner dan Crosby dalam (Ratminto \& Winarsih, 2014:2), pelayanan adalah produk-produk yang tidak kasat mata (tidak dapat diraba) yang melibatkan usaha-usaha manusia dan menggunakan peralatan. Sedangakan definisi yang lebih rinci diberikan oleh Gronroos: pelayanan adalah suatu aktivitas atau serangkaian aktivitas yang bersifat tidak kasat mata (tidak dapat diraba) yang terjadi sebagai akibat adanya intraksi antara konsumen dengan karyawan atau hal-hal lain yang disediakan oleh perusahaan pemberi pelayanan yang dimaksudkan untuk memecahkan permasalahan konsumen/pelanggan.

Dari dua definisi tersebut di atas dapat diketahui bahwa ciri pokok pelayanan adalah tidak kaat mata (tidak dapat diraba) dan melibatkan upaya manusia (karyawan) atau peralatan lain yang disediakan oleh perusahaan penyelenggara pelayanan. Ciri-ciri lain yang lebih lengkap yang dapat dipakai untuk memahami pengertian pelayanan telah diberikan oleh Zemke sebagaimana dikutip oleh Collins dan McLaughlin dalam (Ratminto \& Winarsih, 2014 : 3) sebagaimana dapat dilihat dalam tabel dibawah ini.

Tabel 2. Karaketer istik produk (barang) dan pelayanan

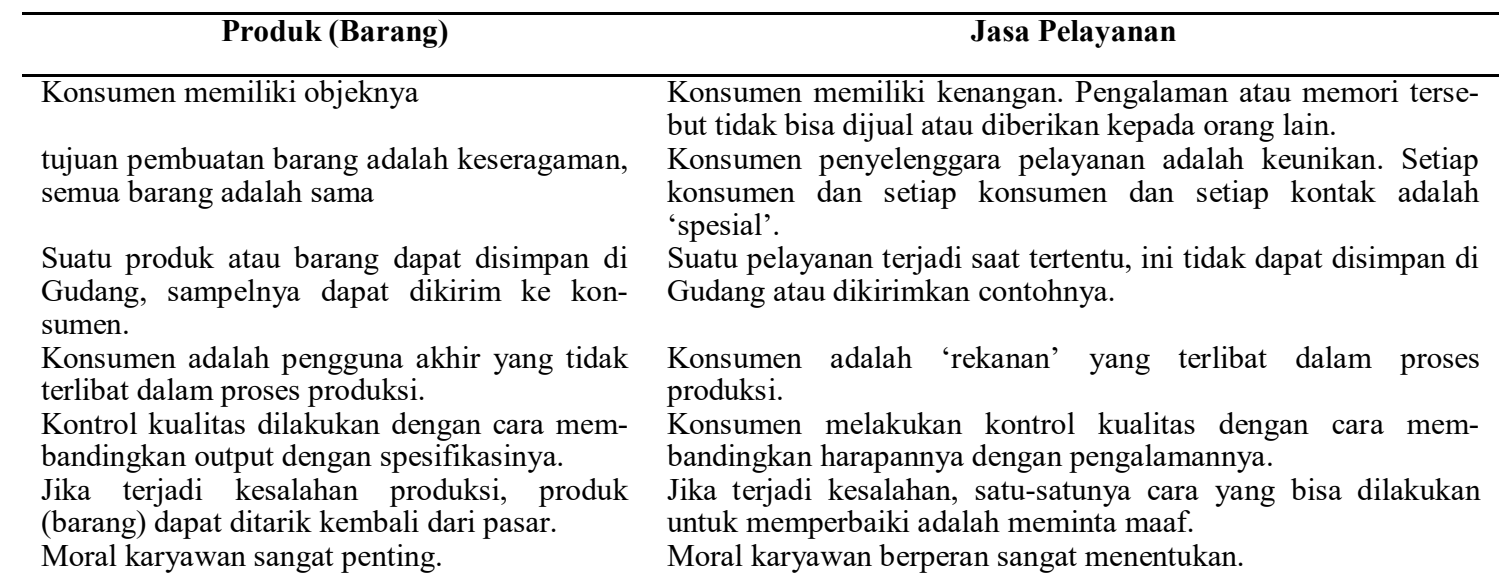


Prosedur pelayanan yang pertama berdasarkan hasil penelitian menyatakan bahwa Bagian Tata Usaha SLBN A Kota Bandung yang menerima publik akademik. Sedangkan menurut (Kriyantono, 2015), menyebutkan bahwa "public relations is the watch dog of corporate interest and public expectations and as such counsels the management for the formation of new policies, procedures, and actions, which are mutually beneficial to organization and publics". (public relations adalah sebagai penjaga paling depan kepentingan perusahaan dan harapan publik dan dengan demikian menasihati manajemen untuk pembentukan kebijakan, prosedur, dan tindakan baru, yang saling menguntungkan bagi organisasi dan publik). Betapa pentingnya posisi Humas di suatu Lembaga seperti yang diungkapkan diatas untuk berhadapan langsung dengan setiap publiknya.

Humas yang dikutip dari (Rahmad, 2016:78) Pertama, Jika dilihat dari sudut pandang manajemen, humas adalah suatu realisasi fungsi komunikasi sementara tugas humas itu sendiri merupakan salah satu fungsi manajemen. Kedua, Jika ditinjau dari sudut pandang administrasi pendidikan, hu- mas adalah bagian atau salah satu komponen kegiatan administrasi pendidikan, dalam hal ini di sekolah. Realisasinya adalah kegiatan yang dilakukan sekolah bersama-sama dengan masyarakat. Kegiatan sekolah yang berhubungan dengan masyarakat diarahkan pada terciptanya kerja sama yang harmonis antara sekolah dan masyarakat.

Suatu keharmonisan tersebut dapat diciptakan oleh Humas tentunya dengan keahlian komunikasi yang dilakukannya. Memang pada kenyataannya posisi humas dalam struktur organisasi sekolah di Indonesia baik sekolah negeri maupun sekolah swasta sangat beragam. Hal ini dikarenakan faktor eksistensi sekolah disesuaikan dengan situasi dan kondisi yang ada di masing-masing sekolah, seperti jumlah siswa, manajemen sekolah, peraturan yang berlaku, dan sebagainya.

Di dalam keputusan MENPAN Nomor 63 Tahun 2003 disebutkan bahwa penyelenggaraan pelayanan harus memenuhi beberapa prinsip. Salah satu prinsipnya adalah kesederhanaan yang berarti prosedur pelayanan publik tidak berbelit-belit, mudah dipahami dan mudah dilaksanakan (Ratminto 
\& Winarsih, $2014: 21-23)$. Oleh karena itu aspek pelayanan kepada publik dapat dievaluasi melalui analisis kinerja humas (Rahmat \& Bakti, 2016).

Setiap penyelenggaran pelayanan publik harus memiliki standar pelayanan dan dipublikasikan sebagai jaminan adanya kepastian bagi penerima pelayanan. Standar pelayanan merupakan ukuran yang dibakukan dalam penyelenggaraan pelayanan publik yang wajib ditaati oleh pemberi dan atau penerima pelayanan. Menurut Keputusan MENPAN Nomor 63 Tahun 2004, standar pelayanan, sekurang-kurangnya meliputi prosedur pelayanan yakni prosedur pelayanan yang dibakukan bagi pemberi dan penerima pelayanan termasuk pengaduan (Ratminto \& Winarsih, 2014: 23:24).

Dalam kaitannya dengan pola pelayanan, Keputusan Menteri Pendayagunaan Aparatur Negara Nomor 63 Tahun 2004 menyatakan adanya empat pola pelayanan, yaitu. (a) Fungsional: Pola pelayanan publik diberikan oleh penyelenggara pelayanan, sesuai dengan tugas, fungsi dan kewenangannya. (2) Terpusat: Pola pelayanan publik diberikan secara tunggal oleh penyelenggara pelayanan berdasarkan pelimpahan wewenang dari penyelenggara pelayanan terkait lainnya yang bersangkutan. (3) Terpadu: Pola penyelenggaraan pelayanan publik terpadu dibedakan menjadi dua, yaitu Terpadu satu atap (Pola pelayanan terpadu satu atap diselenggarakan dalam satu tempat yang meliputi berbagai jenis pelayanan yang tidak mempunyai keterkaitan proses dan dilayani melalui beberapa pintu. Terhadap jenis pelayanan yang sudah dekat dengan masyarakat tidak perlu disatuatapkan) dan Terpadu satu pintu (Pola pelayanan terpadu satu pintu diselenggarakan pada satu tempat yang meliputi berbagai jenis pelayanan yang memiliki keterkaitan proses dan dilayani melalui satu pintu). Terakhir (4) gugus tugas: Petugas pelayanan publik secara perorangan atau dalam bentuk gugus tugas ditempatkan pada instansi pemberi pelayanan dan lokasi pemberian pelayanan tertentu. Sehingga dapat tercipta profesionalisme, sebab, kompetensi profesional seorang guru berhubungan dengan penyelesaian tugastugas keguruan dan berhubungan langsung dengan kinerja yang ditampilkan (Hafiar, Subekti, Damayanti, \& Sjoraida, 2015), 
termasuk dalam melayani kebutuhan masyarakat.

Selain pola pelayanan sebagaimana yang telah disebutkan di atas, instansi yang melakukan pelayanan publik dapat mengembangkan pola penyelenggaraan pelayanannya sendiri dalam rangka upaya menemukan dan menciptakan inovasi peningkatan pelayanan publik. (Ratminto \& Winarsih, 2014: 25-26). Sehingga dapat dikatakan bahwa prosedur pelayanan di SLBN A Kota Bandung akan jauh lebih baik menggunakan pola pelayanan Terpadu satu pintu yang akan membuat publik akademik kemudahan dalam mencari informasi.

\section{SIMPULAN}

Berdasarkan hasil penelitian dan pembahasan yang telah diperoleh peneliti mengenai komunikasi dalam pelayanan kepada publik akademik di SLBN A Kota Bandung, maka peneliti menarik kesimpulan adalah Prosedur komunikasi dalam pelayanan publik akademik memiliki tujuh tahapan di antaranya menghubungi Tata Usaha (TU) bagi PPL/ PPG/KKN, Surat Rekomendasi Dinas Pendidikan Provinsi Jawa Barat bagi peneliti, Disposisi Kepala Sekolah, Koordinasi JadNo. SK Akreditasi Ristekdikti : 34/E/KPT/2018 wal Lapangan, Mengkondisikan Objek, Pendampingan Publik oleh Penanggung Jawab/ Guru Pamong dan Menyerahkan Laporan Hasil Kegiatan.

Berdasarkan penjelasan dan kesimpulan yang telah disampaikan, maka berikut adalah saran yang dapat dilakukan oleh Bagian $\mathrm{Hu}-$ mas dan sekolah, yaitu: Dalam prosedur komunikasi dalam pelayanan publik akademik di SLBN A Kota Bandung, pelibatan peran humas sangat minim padahal humas bertanggung jawab untuk memberikan informasi yang pertama kepada publiknya. Oleh karena itu sebaiknya dioptimalisasikan perannya agar kendala pengkoordinasian antara sekolah dengan guru sekolah dengan orang tua, sekolah dengan publik akademik, dan sekolah dengan siswa berjalan dengan lancar. Sehingga dapat mengurangi beban sekolah

\section{DAFTAR PUSTAKA}

Ardianto, E. (2011). Handbook of Public Relations Pengantar Komprehensif. Bandung: Simbiosa Rekatama Media. Hafiar, H., Subekti, P., Damayanti, T., \& Sjoraida, D. F. (2015). Peningkatan Pendidikan Dan Pengembangan Kompetensi Guru SMA Negeri 1 Katapang Melalui Partisipasi Dalam Publikasi 
Akademis Di Media Massa. Jurnal Dharmakarya, 4(2), 88-92.

Isharwati. (2008). Mengenali penyandang tunanetra dan intervensi pendidikannya. Makalah Pelatihan Bagi Staff YAKKUM Tentang Rehabilitasi Dasar Untuk Semua Jenis Kecacatan.

kbbi.web.id. (n.d.). Prosedur.

Kriyantono, R. (2015). Konstruksi Humas Dalam Tata Kelola Komunikasi Lembaga Pendidikan Tinggi di Era Keterbukaan Informasi Publik. Jurnal Pekommas, 18(2), 117-126.

Kurnia, I. H., Santoso, D., \& Rahmanto, A. (2013). Reputasi Sekolah ( Studi Kasus di SMA Negeri 1 Surakarta ). Jupe UNS, I(2).

Prastantri, A. S., Novianti, E., \& Romli, R. (2017). Identitas Sekolah Cinta Budaya Bangsa Indonesia Pada Sekolah Cakra Buana. Jurnal Profesi Humas, 2/1(1), 73-85.

Pratama, D., Hakim, D. ., Prasetya, Y., Febriandika, N. ., Trijati, M., \& Fadlilah, U. (2016). Rancang Bangun Alat dan Aplikasi untuk Para Penyandang Tunanetra Berbasis Smartphone Android. Ilmu Komputer Dan Informatika, 2(1), 14-19.

Rahmad, A. (2016). Manajemen Humas Sekolah. Media Akademi (1st ed.). Yogyakarta: Media Akademi.

Rahmat, A., \& Bakti, I. (2016). Kinerja Hubungan Masyarakat (Humas) Pemerintah daerah Kabupaten dan Kota di Jawa Barat. Jurnal Kajian Komu- nikasi, 4/2, 133-141.

Ratminto, \& Winarsih, A. S. (2014). Manajemen Pelayanan: Pengembangan Model Konseptual, Penerapan Citizen's Charter dan Standar Pelayanan Minimal.

scribd.com. (n.d.). Buku Panduan PPL Bagi Mahasiswa UPI Calon Guru Bidang Studi. 